\title{
Mixing between a stratospheric intrusion and a biomass burning plume
}

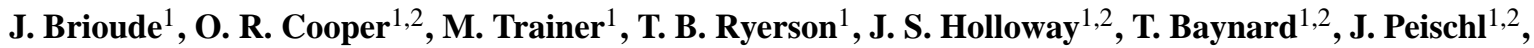 \\ C. Warneke ${ }^{1,2}$, J. A. Neuman ${ }^{1,2}$, J. De Gouw ${ }^{1,2}$, A. Stohl ${ }^{3}$, S. Eckhardt ${ }^{3}$, G. J. Frost ${ }^{1,2}$, S. A. McKeen ${ }^{1,2}$, E.-Y. Hsie ${ }^{1,2}$, \\ F. C. Fehsenfeld ${ }^{1,2}$, and P. Nédélec ${ }^{4}$ \\ ${ }^{1}$ Chemical Sciences Division, Earth Science Reasearch Laboratory, NOAA, Boulder, Colorado, USA \\ ${ }^{2}$ Cooperative Institute for Research in Environmental Sciences, University of Colorado, Boulder, Colorado, USA \\ ${ }^{3}$ Norwegian Institute for Air Research, Kjeller, Norway \\ ${ }^{4}$ Laboratoire d'Aérologie, UMR 5560, Observatoire Midi-Pyrénées, Toulouse, France
}

Received: 4 May 2007 - Published in Atmos. Chem. Phys. Discuss.: 8 June 2007

Revised: 15 August 2007 - Accepted: 16 August 2007 - Published: 20 August 2007

\begin{abstract}
Ozone, carbon monoxide, aerosol extinction coefficient, acetonitrile, nitric acid and relative humidity measured from the NOAA P3 aircraft during the TexAQS/GoMACCS 2006 experiment, indicate mixing between a biomass burning plume and a stratospheric intrusion in the free troposphere above eastern Texas. Lagrangianbased transport analysis and satellite imagery are used to investigate the transport mechanisms that bring together the tropopause fold and the biomass burning plume originating in southern California, which may affect the chemical budget of tropospheric trace gases.
\end{abstract}

\section{Introduction}

Since the pioneering work of Danielsen (1968), tropopause folds have been a focus of atmospheric research because they are one of the main sources of stratospheric ozone flux into the troposphere. They occur in cutoff lows (Price and Vaughan, 1993) or in frontal systems, and are more frequent near the subtropics (between $20^{\circ} \mathrm{N}$ and $40^{\circ} \mathrm{N}$ ) than further poleward (Sprenger et al., 2003). The net ozone flux across the tropopause is downward from the stratosphere to the troposphere at midlatitudes, with a maximum in winter/spring and minimum in summer/fall (Sprenger and Wernli, 2003). Using a 15-year climatology of cross tropopause exchange, James et al. (2003) have shown that stratospheric airmasses over United States reach the lower troposphere above southeastern United States and the northern part of the Gulf of Mexico in winter. In summer, the impact of stratospheric airmasses is much weaker and is most prominent above the northern United States. Much attention has been paid to

Correspondence to: J. Brioude

(jerome.brioude@noaa.gov) the decay of tropopause folds in the troposphere because the ozone that they contain contributes to the $O H$ radical concentration which affects the chemical budget of different trace gases in the troposphere (Esler et al., 2001). Kentarchos and Roelofs (2003) have shown that the stratospheric ozone flux contributes up to $15 \%$ to the tropospheric $O H$ radical concentration in the Northern Hemisphere. To have a large impact on the tropospheric ozone concentration, the stratospheric air in the fold must mix irreversibly with the surrounding tropospheric air. Previous studies have shown that tropopause folds can disperse into decaying warm conveyor belts (Cooper et al., 2004), and they can also be interleaved with anthropogenic pollution (Cho et al., 2001; Parrish et al., 2000). Irreversible Stratosphere-Troposphere Exchange (STE) occurs between these layers at small scales resulting in a layer with elevated ozone and reduced $\mathrm{CO}$ relative to adjacent unimpacted tropospheric air. Another common, but completely unrelated, influence on the composition of the troposphere arises from biomass burning (BB) emissions. BB is known to be one of the main sources of aerosols, carbon monoxide (CO), volatile organic compounds and nitrogen oxides (NOx) in the troposphere (Andreae and Merlet, 2001). During the summer 2004 NEAQS-ITCT 2k4 study period, plumes from Alaska and western Canada were sampled on multiple flights above the eastern United States (de Gouw et al., 2006). In the region of New York and Boston, $\mathrm{BB}$ was more important than anthropogenic $\mathrm{CO}$ sources at altitudes between 3 and $5 \mathrm{~km}$ (Warneke et al., 2006). BB can also affect ozone concentrations at the continental scale. During the summer of 1995, large forest fires in northern Canada caused high $\mathrm{CO}$ mixing ratios at ground level in the southern and eastern United States, and were responsible for 10 to $30 \mathrm{ppbv}$ ozone enhancements over a period of 2 weeks (Wotawa and Trainer, 2000; Mckeen et al., 2002). While

Published by Copernicus Publications on behalf of the European Geosciences Union. 
BB plumes and stratospheric intrusions occur frequently in the troposphere, to date, mixing between the two has not been reported. In this case study, we document the first clear case of mixing between a tropopause fold and a BB plume in the free troposphere. The event occurred during the Texas Air Quality Study/Gulf of Mexico Atmospheric Composition and Climate Study (Tex- AQS/GoMACCS), conducted during August-October 2006 across eastern Texas and the northwestern Gulf of Mexico to investigate the influence of anthropogenic trace gases and aerosol emissions on the air quality and radiative balance of the region. In this paper, we use in-situ measurements of ozone, carbon monoxide, aerosol extinction coefficient, acetonitrile, nitric acid and relative humidity measured from the NOAA P3 aircraft to study the chemical signature of mixing between a BB plume and a stratospheric intrusion. We use a Lagrangian particle dispersion model and satellite imagery to investigate the transport mechanisms that bring together the tropopause fold and the BB plume. Section 2 presents the in-situ measurements and the modeling methods. Section 3 presents the analysis of observations, model calculations and satellite imagery. Finally, conclusions are drawn in Sect. 4.

\section{Method}

\subsection{In-situ measurements}

CO on the NOAA WP-3D research aircraft was measured once per second using using vacuum ultraviolet resonance fluorescence (Holloway et al., 2000) with an uncertainty of $\pm 5 \%$. Ozone was measured with an uncertainty of $\pm(0.1 \mathrm{ppbv}+3 \%)$.

The aerosol extinction coefficient $\left(\sigma_{e p}, 532 \mathrm{~nm}, 10 \% \mathrm{RH}\right)$ was measured using a cavity ring-down technique and dried to $\mathrm{RH} \leq 10$ with an uncertainty of $\pm 5 \%$ (Baynard et al., 2006).

Acetonitrile was measured with a PTR-MS instrument for $1 \mathrm{~s}$ every $17 \mathrm{~s}$ (de Gouw and Warneke, 2007) with an uncertainty of $\pm 15 \%$.

Gas phase nitric acid $\left(\mathrm{HNO}_{3}\right)$ was measured once per second using a chemical ionization mass spectrometer (Neuman et al., 2002) with a precision of $\pm 20 \mathrm{pptv}$ and an accuracy of $\pm(15 \%+100 \mathrm{pptv})$.

\subsection{Model description}

To identify the origin of the polluted plume and simulate air pollution transport over North America, we use the FLEXPART Lagrangian particle dispersion model (version 6.2) (Stohl et al., 2005 and references therein). We conducted forward simulations of long-range and mesoscale transport of anthropogenic pollution tracers from North America and emissions from $\mathrm{BB}$ to assess their impact on observed $\mathrm{CO}$ concentrations over Texas and the Gulf of Mexico. FLEXPART was driven by model-level data from the European
Centre for Medium-Range Weather Forecasts (ECMWF), with a temporal resolution of $3 \mathrm{~h}$ (analyses at 00:00, 06:00, 12:00, 18:00 UTC ; 3-h forecasts at 03:00, 09:00, 15:00, 21:00 UTC), and 91 vertical levels. Horizontal resolution was $1^{\circ} \times 1^{\circ}$ globally with nested wind fields at $0.36^{\circ} \times 0.36^{\circ}$ resolution $\left(108^{\circ} \mathrm{W}-27^{\circ} \mathrm{W}, 9^{\circ} \mathrm{N}-54^{\circ} \mathrm{N}\right)$. Anthropogenic $\mathrm{CO}$ emissions from Canada and Mexico were taken from the EDGAR 2000 inventory at $1^{\circ} \times 1^{\circ}$ resolution. Tracer particles were injected between 0 and $150 \mathrm{~m}$ above ground level, representing the mean injection height of point sources and distributed area surface emissions. CO emissions from the United States were based on the EPA 1999 National Emission Inventory at $4 \mathrm{~km} \times 4 \mathrm{~km}$ resolution (Frost et al., 2006). Injection height of point sources in the model is specified in the inventory, while the mean injection height of area sources was between 0 and $20 \mathrm{~m}$. BB CO emissions were calculated using the algorithm of Stohl et al. (2007), which uses fire detection data, information on landuse and applies emission factors from Andreae and Merlet (2001). We used an injection height between 0 and $5 \mathrm{~km}$, and assessed the area burned with the National Interagency Coordination Center Incident Management Report of forest fires. The passive BB $\mathrm{CO}$ tracer was allowed to advect for either 5 or 15 days, after which it was removed from the simulation. A stratospheric ozone tracer was initialized within the model domain and continually released at the model boundaries $\left(130^{\circ} \mathrm{W}-\right.$ $55^{\circ} \mathrm{W}, 10^{\circ} \mathrm{N}-61^{\circ} \mathrm{N}$ ), and allowed to advect with ECMWF winds within the domain (Stohl et al., 2000; Cooper et al., 2005). A linear relationship between ozone and potential vorticity of $50 \mathrm{ppbv} / \mathrm{pvu}$ was used for the month of September (Stohl et al., 2000). The stratospheric ozone is treated as a passive tracer, and its distribution in the troposphere is only due to transport from the stratosphere. Concentration fields were output every hour as 1 - $\mathrm{h}$ averages at $0.6^{\circ} \times 0.6^{\circ}$ grid spacing above the USA and Mexico, and $0.15^{\circ} \times 0.15^{\circ}$ grid spacing above Texas and the Gulf of Mexico. The FLEXPART tracers are only 15 days old and must be considered as mixing ratios above background. In addition, backward simulations started along the aircraft flight track were used to retrieve the distribution of the different source regions of the pollutants.

\section{Analysis}

Figure 1 presents time series of (top) ozone, $\mathrm{CO}, \sigma_{e p}, \mathrm{HNO}_{3}$ (pptv), acetonitrile $\left(\mathrm{CH}_{3} \mathrm{CN}\right.$, pptv/2) and (bottom) measurements of altitude and relative humidity, over Texas from the NOAA P3 aircraft flight on 25 September 2006. $\sigma_{e p}$ and acetonitrile (de Gouw et al., 2003; Warneke et al., 2006) can be used as biomass burning tracers. Positive correlations between $\mathrm{CO}, \sigma_{e p}$ and acetonitrile indicate the biomass burning origin of $\mathrm{CO}$ enhancements. $\mathrm{HNO}_{3}$ can be used as a stratospheric tracer. Positive correlations between $\mathrm{HNO}_{3}$ and ozone indicate a stratospheric origin of ozone enhancements. 

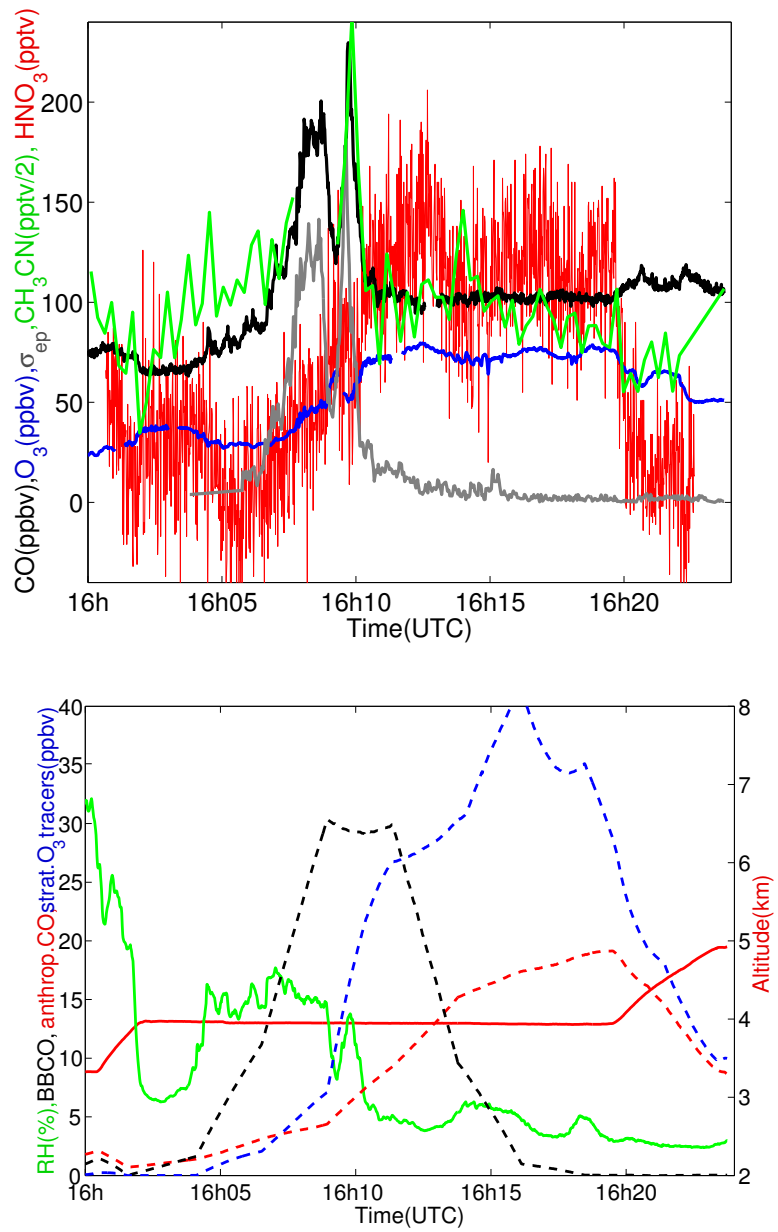

Fig. 1. Top: NOAA P3 time series of CO (black line, ppbv), ozone (blue line, ppbv), $\sigma_{e p}$ (gray line, $\mathrm{Mm}^{-1}$ ), acetonitrile (green line, pptv/2) and nitric acid (red line, pptv) on September 25 between 16:00 and 16:25 UTC.

Bottom NOAA P3 time series of altitude (red solid line, $\mathrm{km}$ ) and relative humidity (green solid line, $\%$, right vertical axis). Also shown are the FLEXPART biomass burning CO tracer (black dashed line, ppbv), anthropogenic CO tracer (red dashed line, ppbv) and stratospheric ozone tracer (blue dashed line, ppbv).

At $4 \mathrm{~km}$ altitude, a CO peak (up to $220 \mathrm{ppbv}$ ) is followed by an ozone peak (up to $80 \mathrm{ppbv}$ ) around 16:10 UTC. The only significant $\sigma_{e p}$ and acetonitrile enhancement occurs during the time period of the main two CO peaks. The enhancements of $\mathrm{CO}, \sigma_{e p}$ and acetonitrile and their enhancement ratios to $\mathrm{CO}_{2}$ (not shown) suggest a biomass burning origin rather than anthropogenic pollution. From $16 \mathrm{~h} 05$ to $16 \mathrm{~h} 15$, the enhancement of ozone (from 30 to $80 \mathrm{ppbv}$ ) is positively correlated with the nitric acid (from 30 to $150 \mathrm{pptv}$ ) and negatively correlated with relative humidity. The $\mathrm{HNO}_{3}$ to ozone slope is $\mathrm{HNO}_{3}[\mathrm{ppbv}]=0.0022 * \mathrm{O}_{3}[\mathrm{ppbv}]-0.055$, and is consistent with previous measurements obtained in the lower stratosphere $\left(\mathrm{HNO}_{3}[\mathrm{ppbv}]=0.0023 * \mathrm{O}_{3}-0.064\right.$, Neuman et al., 2001).
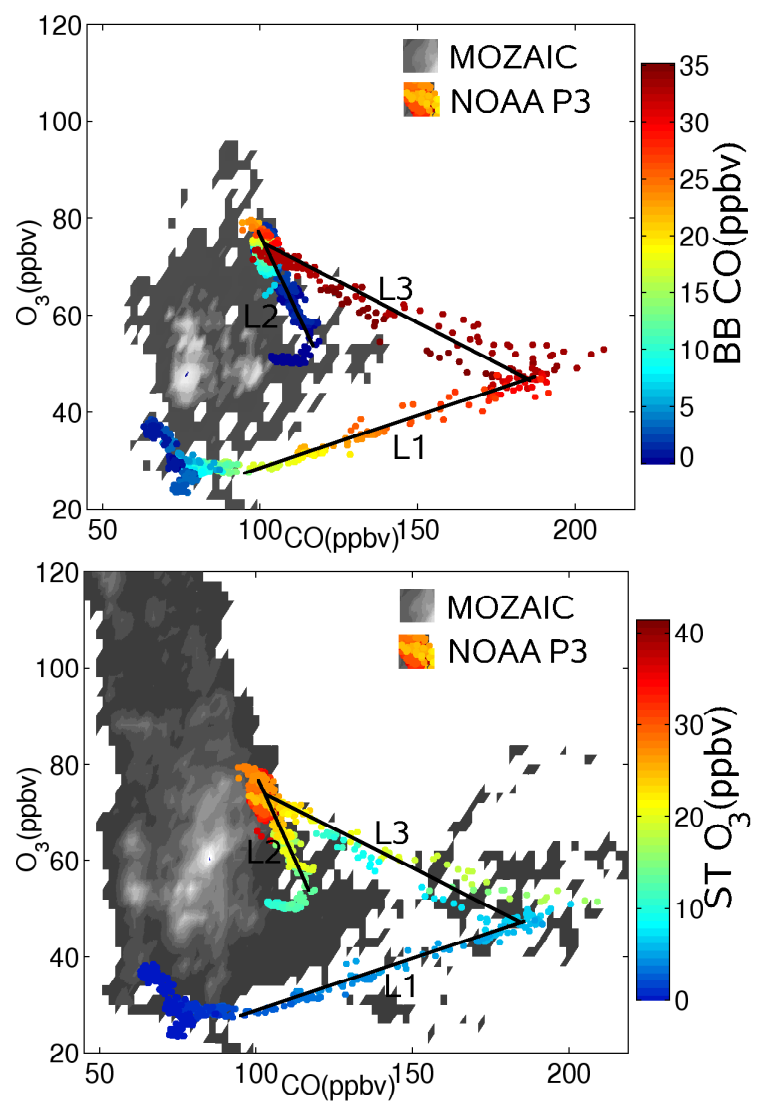

Fig. 2. NOAA P3 ozone and CO mixing ratios on 25 September, 16:00-16:25 UTC, colored by (top) the modeled biomass burning $\mathrm{CO}$ tracer (BBCO, ppbv) and (bottom) by the stratospheric ozone tracer $\left(\mathrm{ST} \mathrm{O}_{3}\right.$, ppbv). The grey background represents the distribution of MOZAIC ozone and CO measurements in (top) the free troposphere (defined by $300 \mathrm{hPa} \leq$ pressure $\leq 800 \mathrm{hPa}$ ) and (bottom) the entire troposphere/lowermost stratosphere (pressure $\geq 300 \mathrm{hPa}$ ). Lighter (darker) shading indicates a greater (lesser) number of measurements. The gray shading is based on 27 MOZAIC flights. The most frequent ozone/CO grid cell measured by the MOZAIC flights (white color) is related to 194 data points in the entire troposphere/lowermost stratosphere (bottom), and 62 data points in the free troposphere (top).

Figure 2 compares the observed ozone and $\mathrm{CO}$ measurements from Fig. 1 (colored dots) to the ozone and $\mathrm{CO}$ distributions in the free troposphere (top) and the entire troposphere/lowermost stratosphere (bottom) retrieved from MOZAIC (Measurements of Ozone, Water Vapour, Carbon Monoxide and Nitrogen Oxides by Airbus in service aircraft, Thouret et al., 1998; Nedelec et al., 2003) profiles (grey background) over Houston, Dallas and Atlanta, in September 2003 and 2004. Most of the MOZAIC ozone and CO mixing ratios in the free troposphere are between 40 and $60 \mathrm{ppbv}$ of ozone and 70 to $100 \mathrm{ppbv}$ of CO. Comparing Fig. 2(top) and (bottom), the vertical branch of Fig. 2(bottom) is related to upper tropospheric measurements while the horizontal branch is related to lower tropospheric measurements. 


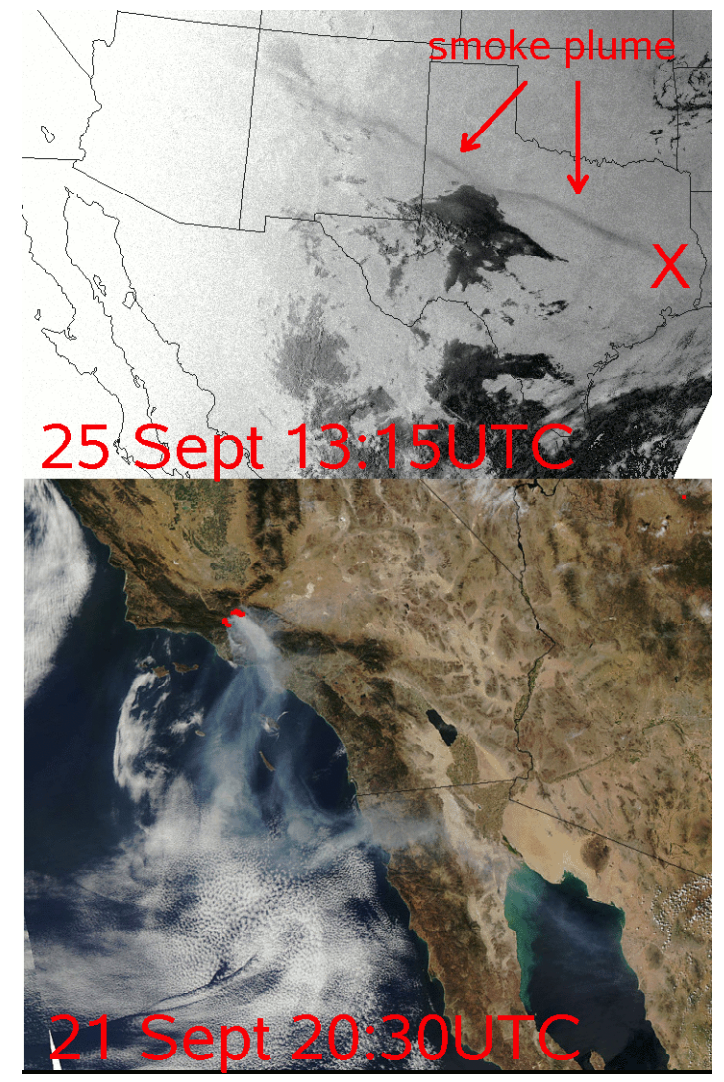

Fig. 3. Top: Visible channel of the GOES East imager, 13:15 UTC 25 September. Dark areas represent clouds or aerosol plumes and light areas represent clear air or the night time region, as the sun was rising in the east at this time. The red cross represents the aircraft position at 16:10 UTC.

Bottom: Southern California and northern Baja California as depicted by the visible channel of MODIS on the Aqua satellite, at 20:30 UTC, 21 September. The red dots represent active fires.

Two processes are visible in the P3 data in this figure. The first one is exemplified by the positive correlation between ozone and CO (labeled line L1). It may be related to photochemical production of ozone in a pollution plume (with up to $200 \mathrm{ppbv}$ of $\mathrm{CO}, 50 \mathrm{ppbv}$ of ozone).The second process is demonstrated by a negative correlation between ozone and $\mathrm{CO}$ with two different negative slopes (labeled lines L2 and L3). This process may be due to STE (e.g. Hoor et al., 2002), since negative ozone/CO slopes seen in MOZAIC data are related to the mean vertical branch of the upper troposphere.

Figure 1(bottom) shows the time series of the modeled BB and anthropogenic $\mathrm{CO}$ tracers and the stratospheric ozone tracer, from the nested domain output, linearly interpolated along the aircraft flight track. At about 16:10 UTC, a welldefined BB CO tracer peak lies at the same position as the P3 $\mathrm{CO}$ and $\sigma_{e p}$ peaks, while a small anthropogenic tracer contribution is modeled at this time. The BB CO tracer peak is underestimated (35 ppbv) compared with the $\mathrm{P} 3 \mathrm{CO}$ peak (up to $120 \mathrm{ppbv}$ above the $\mathrm{CO}$ background). However, the width of the $\mathrm{P} 3 \mathrm{CO}$ peak is about $6 \mathrm{~km}$ (1 min with an aircraft ground speed of $100 \mathrm{~ms}^{-1}$ ) which is quite small compared to the simulation output scale $\left(0.15^{\circ} \times 0.15^{\circ}\right)$. The integral of the measured $\mathrm{CO}$ enhancement relative to the background is 14864 ppbv s, while the integrated modeled BB CO peak is 14115 ppbv s, or about $95 \%$ of the integrated measurement. Thus, the model suggests that the sampled $\mathrm{CO}$ peak is mainly due to a BB plume.

The modeled anthropogenic $\mathrm{CO}$ tracer is correlated with measured $\mathrm{CO}$ except at the time of the two main $\mathrm{CO}$ peaks. At 16:00 UTC, the P3 background CO is about 65 ppbv while the modeled anthropogenic $\mathrm{CO}$ tracer is close to zero. Backward trajectories give a Pacific Ocean origin for this time period (not shown). At 16:15 UTC the measured background $\mathrm{CO}$ is about $95 \mathrm{ppbv}$ and the modeled anthropogenic $\mathrm{CO}$ tracer is 20 ppbv. This airmass comes from western Texas, New Mexico and Arizona (not shown). Therefore the increase in measured background $\mathrm{CO}(30 \mathrm{ppbv})$ is due to influence from anthropogenic pollution.

Figure 2 is colored by the modeled stratospheric ozone tracer (bottom) and by the BB CO tracer (top). The 5-day BB tracer shows that the positive correlation between ozone and $\mathrm{CO}$ (from $30 \mathrm{ppbv}$ of ozone and $100 \mathrm{ppbv}$ of $\mathrm{CO}$ to $50 \mathrm{ppbv}$ of ozone and $180 \mathrm{ppbv}$ of CO, labeled line L1) is related to mixing between relatively clean background air and the biomass burning plume. The stratospheric ozone tracer indicates that an air mass with a significant stratospheric component (100 ppbv of CO and $80 \mathrm{ppbv}$ of ozone) mixed with both a relatively clean tropospheric airmass ( $115 \mathrm{ppbv}$ of $\mathrm{CO}$ and $55 \mathrm{ppbv}$ of ozone, labeled line L2) and the BB plume (200 ppbv of CO and 50 ppbv of ozone, labeled line L3). Applying a 15-day BB CO tracer only increases the BB CO peak value by 2 ppbv. Therefore the BB plume appears to be primarily less than 5 days old.

The anticorrelations between the BB CO and stratospheric ozone tracers, $\mathrm{P} 3$ ozone and $\mathrm{CO}$, and $\mathrm{P} 3$ relative humidity and $\mathrm{CO}$, reinforce the hypothesis of mixing between a stratospheric intrusion and a biomass burning plume.

Figure 3 (top) presents the visible channel of the GOESEast satellite at 13:15 UTC, 25 September, $3 \mathrm{~h}$ before the aircraft sampled the BB plume. A narrow plume is visible north of the aircraft position at 16:10 UTC (red cross), and extends from eastern Texas to western New Mexico. This narrow plume is only visible at sunrise when the sun is low in the sky and the underlying surface is not bright.

FLEXPART backward calculations were used to locate the source region of the BB CO that contributed to the two P3 CO peaks. Figure 4 presents the percentage of surface contribution to the BB CO mixing ratios, scaled according to the maximum surface contribution encountered in the domain output (red pixel). It shows that the main source is located north of Los Angeles.

On 21 September 20:30 UTC (Fig. 3 bottom), the visible channel of the MODIS satellite instrument shows a large 


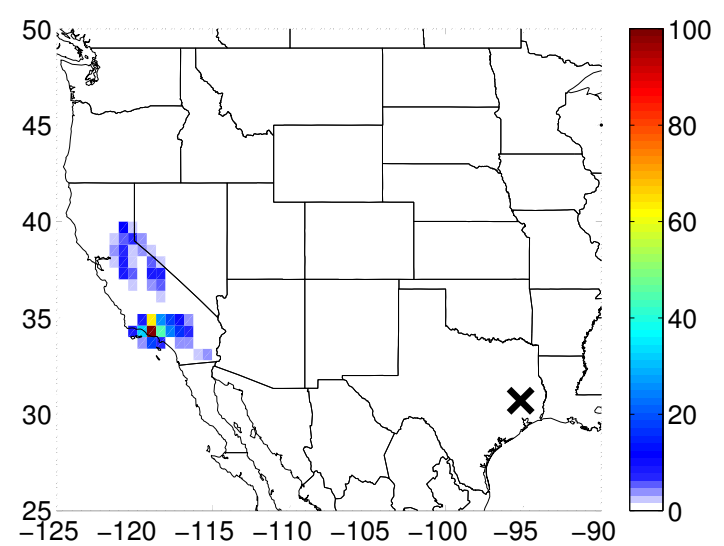

Fig. 4. Percentage of $\mathrm{CO}$ surface contribution of the $\mathrm{CO}$ peak measured at about 16:10 UTC due to biomass burning in the main domain output, scaled according to the maximum contribution encountered in the domain output (red pixel).

forest fire located in the Los Padres National Forest north of Los Angeles at the same location as the BB contribution simulated by FLEXPART. The NASA Earth Observatory (http://earthobservatory.nasa.gov/Newsroom/NewImages/ images.php3?img_id=17408) reports that this fire began on 4 September and burned with varying intensity until the end of September.

A supplemental animation (http://www.atmos-chem-phys. net/7/4229/2007/acp-7-4229-2007-supplement.zip) shows the transport of the modeled BB plume from this forest fire (blue) and the transport of stratospheric intrusions (green), for the period 12:00 UTC 21 September to 18:00 UTC 25 September. Red areas represent mixing regions where the BB plume and stratospheric intrusion are colocated. From 12:00 UTC 21 September to 12:00 UTC 22 September the BB plumes produced near Los Angeles remained in the southwestern United States. During this time a large upper level low became established above the central United States with a strong cold front draped across the south-central USA. This system produced westerly flow in the lower and mid-troposphere across the western USA which allowed a portion of the BB plume to reach the eastern USA by 12:00 UTC 23 September. The influence of the upper level low persisted and other portions of the BB plume advected eastward from southern California on 24 September until they reached east Texas on 25 September. Meanwhile a large and deep stratospheric intrusion produced by the upper level low penetrated into the lower troposphere and advected eastward with the same flow pattern along the poleward edge of the BB plume. By 03:00 UTC 24 September portions of the stratospheric intrusion began to disperse into the BB plume above the southwestern USA (red regions in the movie). The plumes continued to mingle as they advected
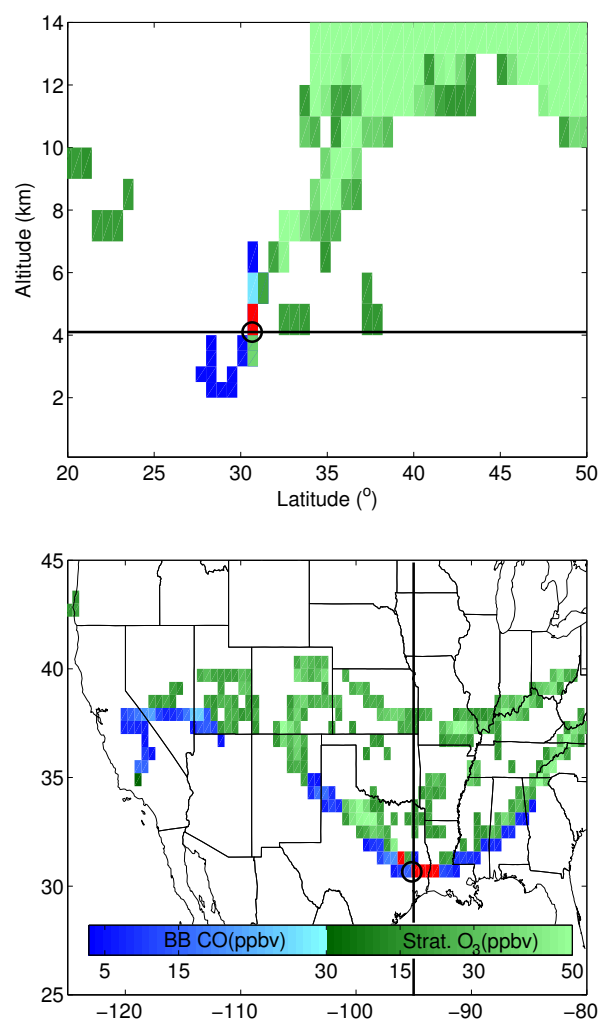

Fig. 5. (Top) Vertical and (Bottom) horizontal cross sections of the FLEXPART stratospheric ozone tracer (green) and the biomass burning tracer (blue) at 16:00 UTC, 25 September. Grid cells containing both tracers are shaded red. The black circles indicate the aircraft position at 16:10 UTC and the black lines indicate the altitude of the horizontal cross section (top) and the longitude of the meridional cross section (bottom).

eastward. At 15:00 UTC 25 September, the southern part of the comingled plumes was located above east Texas where the NOAA P3 aircraft sampled it at 16:10 UTC.

Figure 5 (bottom) presents a horizontal cross section of the FLEXPART stratospheric ozone tracer at $4 \mathrm{~km}$ altitude and the mean BB CO tracer between 3 and $5 \mathrm{~km}$ altitude. The BB plume lies next to the tropopause fold from Texas to the Great Lakes region. The narrow BB plume seen in the GOES image (Fig. 3, top) is well simulated by FLEXPART (Fig. 5, bottom). Figure 5 (top) presents a meridional vertical cross section at the longitude of the aircraft position at 16:10 UTC (black circle in Fig. 5, bottom). A potential mixing region (red pixels) is identified between 3 and $5 \mathrm{~km}$, using a threshold of $10 \mathrm{ppbv}$ for the BB CO tracer and $15 \mathrm{ppbv}$ for the stratospheric ozone tracer, in the vicinity of the NOAA P3 aircraft (black circle). 


\section{Discussion}

Ozone, carbon monoxide, aerosol extinction coefficient, acetonitrile, nitric acid and relative humidity measured from the NOAA P3 aircraft during the TexAQS/GoMACCS 2006 experiment, show evidence of mixing between a tropopause fold and a biomass burning plume above east Texas at 16:00 UTC on 25 September 2006. We used the FLEXPART Lagrangian particle dispersion model to simulate biomass burning transport and stratospheric intrusions. We found that a biomass burning plume originating north of Los Angeles was mixed with air from a tropopause fold that originated above the central United States. This Lagrangian-based study confirms that mixing does occur between biomass burning plumes and stratospheric intrusions in the free troposphere. But is this a common occurence? To answer this question we performed a statistical analysis using FLEXPART forward simulations from 15 August to 1 October 2006 to assess the frequency of such mixing in the Texas region $\left(110^{\circ} \mathrm{W} 90^{\circ} \mathrm{W}, 35^{\circ} \mathrm{N} 28^{\circ} \mathrm{N}\right)$ during September. We used the same FLEXPART parameterization for stratospheric tracers and biomass burning as used for this case study, but assuming an area burned of 180 ha per fire detection (Stohl et al., 2007). A stratospheric intrusion was deemed to be present within a grid cell if the ozone tracer mixing ratio exceeded $30 \mathrm{ppbv}$, and a biomass burning plume was deemed present if the biomass burning tracer mixing ratio exceeded 10 ppbv. Two stratospheric intrusions were found at the surface of the Texas region in September. These intrusions were mixed with biomass burning plumes in $26 \%$ of the grid cells related to the stratospheric intrusions. Between $100 \mathrm{~m}$ and $4 \mathrm{~km}$ of altitude, six stratospheric intrusions were found over Texas, and $40 \%$ was mixed with biomass burning plumes. Between 4 and $8 \mathrm{~km}$, nine stratospheric intrusions were found over Texas, and $8 \%$ was mixed with biomass burning plumes. This percentage decreases with altitude because the biomass burning plumes are less frequent in the free and upper troposphere. These results show that mixing between stratospheric intrusions and biomass burning plumes were relatively common in the lower/free troposphere above Texas during September. This study indicates that mixing between stratospheric intrusions and biomass burning plumes can influence tropospheric chemistry, but further studies are required to determine if such events have any implications for surface air quality.

Acknowledgements. The lead author was supported by a National Research Council Research Associateship Award. The global land cover dataset, as well as the MODIS fire detection data were provided by the University of Maryland from their ftp server. The authors gratefully acknowledge the strong support of the MOZAIC program by the European Communities, EADS, Airbus and the airlines (Lufthansa, Austrian, Air France) who have carried the MOZAIC equipment free of charge since 1994.
Edited by: D. Cziczo

\section{References}

Andreae, M. O. and Merlet, P.: Emission of trace gases and aerosols from biomass burning, Global Biogeochem. Cycles, 15, 955966, 2001.

Baynard, T., Garland, R. M., Ravishankara, A. R., Tolbert, M. A., and Lovejoy, E. R.: Key factors influencing the relative humidity dependence of aerosol light scattering, Geophys. Res. Lett., 33, L06813, doi:10.1029/2005GL024898, 2006.

Cho, J. Y. N., Newell, R. E., Browell, E. V., Grant, W. B., Butler, C. F., and Fenn, M. A.: Observation of pollution plume capping by a tropopause fold, Geophys. Res. Lett., 28, 3243-3246, 2001.

Cooper, O. R., Forster, C., Parrish, D., Dunlea, E., Hubler, G., Fehsenfeld, F., Holloway, J., Oltmans, S., Johnson, B., Wimmers, A., and Horowitz, L.: On the life-cycle of a stratospheric intrusion and its dispersion into polluted warm conveyor belts, J. Geophys. Res., 109, D23S09, doi:10.1029/2003JD004006, 2004.

Cooper, O. R., Stohl, A., Hubler, G., Hsie, E. Y., Parrish, D. D., Tuck, A. F., Kiladis, G. N., Oltmans, S. J., Johnson, B. J., Shapiro, M., Moody, J. L., and Lefohn, A. S.: Direct transport of midlatitude stratospheric ozone into the lower troposphere and marine boundary layer of the tropical Pacific Ocean, J. Geophys. Res., 110, D23310, doi:10.1029/2005JD005783, 2005.

Danielsen, E. F.: Stratospheric-tropospheric exchanges based upon radioactivity, ozone and potential vorticity, J. Atmos. Sci., 25, 502-518, 1968

De Gouw, J. A., Warneke, C., Parrish, D. D., Holloway, J. S., Trainer, M., and Fehsenfeld, F. C.: Emission sources and ocean uptake of acetonitrile $(\mathrm{CH} 3 \mathrm{CN})$ in the atmosphere, J. Geophys. Res., 108(D11), 4329, doi:10.1029/2002JD002897, 2003.

De Gouw, J. A., Warneke, C., Stohl, A., Wollny, A. G., Brock, C. A., Cooper, O. R., Holloway, J. S., Trainer, M., Fehsenfeld, F. C., Atlas, E. L., Donnelly, S. G., Stroud, V., and Lueb, A.: Volatile organic compounds composition of merged and aged forest fire plumes from Alaska and western Canada, J. Geophys. Res., 111, D10303, doi:10.1029/2005JD006175, 2006.

De Gouw, J. and Warneke, C.: Measurements of volatile organic compounds in the earths atmosphere using proton-transferreaction mass spectrometry, Mass Spectrom. Rev., 26(2), 223257, 2007.

Esler J. G., Tan, D. G. H., Haynes, P. H., Evans, M. J., Law, K. S., Plantevin, P. H., and Pyle, J. A.: Stratosphere-troposphere exchange: Chemical sensitivity to mixing, J. Geophys. Res., 106(D5), 4717-4731, doi:10.1029/2000JD900405, 2001.

Frost, G. J., McKeen, S. A., Trainer, M., et al.: Effects of changing power plant NOx emissions on ozone in the eastern United States: Proof of concept, J. Geophys. Res., 111, D12306, doi:10.1029/2005JD006354, 2006.

Holloway, J. S., Jakoubek, R. O., Parrish, D. D., Gerbig, C., VolzThomas, A., Schmitgen, S., Fried, A., Wert, B., B.,, and Drummond, J. R.: Airborne intercomparison of vacuum ultraviolet fluorescence and tunable diode laser absorption measurements of tropospheric carbon monoxide, J. Geophys. Res., 105(D19), 24 251-24 262, 2000.

Honrath, R. E., Owen, R. C., Val Martin, M., Reid, J. S., Lapina, K., Fialho, P., Dziobak, M. P., Kleissl, J., and Westphal, D. L.: 
Regional and hemispheric impacts of anthropogenic and biomass burning emissions on summertime $\mathrm{CO}$ and $\mathrm{O} 3$ in the North Atlantic lower free troposphere, J. Geophys. Res., 109, D24310, doi:10.1029/2004JD005147, 2004.

Hoor, P., Fischer, H., Lange, L., Lelieveld, J., and Brunner, D.: Seasonal variations of a mixing layer in the lowermost stratosphere as identified by the $\mathrm{CO}-\mathrm{O} 3$ correlation from in situ measurements, J. Geophys. Res., 107(D5), 4044, doi:10.1029/2000JD000289, 2002.

James, P., Stohl, A., Forster, C., Eckhardt, S., Seibert, P., and Frank, A.: A 15-year climatology of stratosphere-troposphere exchange with a Lagrangian particle dispersion model: 2. Mean climate and seasonal variability, J. Geophys. Res., 108(D12), 8522, doi:10.1029/2002JD002639, 2003

Kentarchos, A. S., and G. J. Roelofs: A model study of stratospheric ozone in the troposphere and its contribution to tropospheric OH formation, J. Geophys. Res., 108(D12), 8517, doi:10.1029/2002JD002598, 2003.

McKeen, S. A., Wotawa, G., Parrish, D. D., Holloway, J. S., Buhr, M. P., Hubler, G., Fehsenfeld, F. C., and Meagher, J. F.: Ozone production from Canadian wildfires during June and July of 1995, J. Geophys. Res., 107(D14), 4192, doi:10.1029/2001JD000697, 2002.

Nedelec, P., Cammas, J. -P., Thouret, V., Athier, G., Cousin, J. -M., Legrand, C., Abonnel, C., Lecoeur, F., Cayez, G., and Marizy, C.: An improved infrared carbon monoxide analyser for routine measurements aboard commercial Airbus aircraft: technical validation and first scientific results of the MOZAIC III programme, Atmos. Chem. Phys., 3, 1551-1564, 2003, http://www.atmos-chem-phys.net/3/1551/2003/.

Neuman, J. A., Huey, L. G., Dissly R. W. et al.: Fastresponse airborne in situ measurements of $\mathrm{HNO} 3$ during the Texas Air Quality Study, J. Geophys. Res., 107(D20), 4436, doi:10.1029/2001JD001437, 2002.

Parrish, D. D., Holloway, J. S., Jakoubek, R., Trainer, M., Ryerson, T. B., Hubler, G., Fehsenfeld, F. C., Moody, J. L., and Cooper, O. R.: Mixing of anthropogenic pollution with stratospheric ozone: A case study from the North Atlantic wintertime troposphere, J. Geophys. Res., 105, 24 363-24374, 2000.
Price, J., and G. Vaughan: The potential for stratospheretroposphere exchange in cut-off-low systems. Quart. J. Roy. Meteorol. Soc., 119, 343-365, 1993

Reid, H. J. and Vaughan, G.: Convective mixing in a tropopause fold, Q. J. R. Meteorol. Soc.,130, 1195-1221, 2004.

Sprenger, M., and H. Wernli: A northern hemispheric climatology of cross-tropopause exchange for the ERA15 time period (19791993), J. Geophys. Res., 108(D12), 8521, doi:10.1029/2002JD002636, 2003.

Sprenger, M., Croci Maspoli, M., and Wernli, H.: Tropopause folds and cross-tropopause transport: A global investigation based upon ECMWF analyses for the time period March 2000 to February 2001, J. Geophys. Res., 108(D12), 8518, doi:10.1029/2002JD002587, 2003.

Stohl, A., Spichtinger-Rakowsky, N., Bonasoni, P., Feldmann, H., Memmesheimer, M., Scheel, H. E., Trickl, T., Hubener, S. H., Ringer, W., and Mandl, M.: The influence of stratospheric intrusions on alpine ozone concentrations, Atmos. Environ., 34, 1323-1354, 2000.

Stohl, A., Forster, C., Frank, A., Seibert, P., and Wotawa, G.: Technical note: The Lagrangian particle dispersion model FLEXPART version 6.2., Atmos. Chem. Phys., 5, 2461-2474, 2005, http://www.atmos-chem-phys.net/5/2461/2005/.

Stohl, A., Berg, T., Burkhart, J. E., et al.: Arctic smoke-record high air pollution levels in the European Arctic due to agricultural fires in Eastern Europe, Atmos. Chem. Phys., 7, 511-534, 2007, http://www.atmos-chem-phys.net/7/511/2007/.

Thouret, V., Marenco, A., Nedelec, P., and Grouhel, C.: Ozone climatologies at 9-12 km altitude as seen by the MOZAIC airborne program between September 1994 and August 1996, J. Geophys. Res., 103, 25 653-25 679, 1998.

Warneke, C., de Gouw J. A. , Stohl, A. et al.: Biomass burning and anthropogenic sources of $\mathrm{CO}$ over New England in the summer 2004, J. Geophys. Res., 111, D23S15, doi:10.1029/2005JD006878, 2006.

Wotawa, G. and Trainer, M.: The influence of Canadian forest fires on pollutant concentrations in the United States, Science, 288, 324-328, 2000. 